\title{
Characterization of Pseudomonas Species Isolated from the Rhizosphere of Plants Grown in Serozem Soil, Semi-Arid Region of Uzbekistan
}

\author{
Dilfuza Egamberdiyeva \\ Center of Agroecology, University of Agriculture, Tashkent 700128, Uzbekistan \\ E-mail: dilfuza egamberdiyeva@yahoo.com
}

Received February 2, 2005; Revised June 5, 2005; Accepted June 12, 2005; Published July 8, 2005

Collections of native Pseudomonas spp. are kept at the NCAM of Uzbekistan. Some of those organisms were isolated from the rhizosphere of cotton, wheat, corn, melon, alfalfa, and tomato grown in field locations within a semi-arid region of Uzbekistan. Strains used for this study were Pseudomonas alcaligenes, $P$. aurantiaca, $P$. aureofaciens, $P$. denitrificans, $P$. mendocina, $P$. rathonis, and $P$. stutzeri. Some of the pseudomonads have been characterized in this report. These strains produced enzymes, phytohormone auxin (IAA), and were antagonist against plant pathogenic fungi in vitro experiments. Most of the strains were salt tolerant and temperature resistant. Some of the Pseudomonas spp. isolated in this study have been found to increase the growth of wheat, corn, and tomato in pot experiments.

KEYWORDS: Pseudomonas, enzyme, auxin (IAA), wheat, corn, tomato, plant growthpromoting rhizobacteria (PGPR)

\section{INTRODUCTION}

Studies in microbial diversity are important in order to understand the role of microorganisms in the ecology of soil and other ecosystems[1,2,3]. The genus Pseudomonas encompasses arguably the most diverse and ecologically significant group of bacteria on the planet and is found in large numbers in all of the major natural environments and also in associations with plants. This universal distribution suggests a remarkable degree of physiological and genetic adaptability[4].

Investigating the ecology of bacteria associated with plant roots is important to develop an understanding regarding the impact that new agricultural technologies will have on soil ecology, nutrient transformations, and plant succession[5]. Pseudomonas spp. are a major component of the microbial flora, which live in close association with various types of agricultural crops. Their association with plant materials has been related both to their antagonistic activities towards pathogens and to their ability to colonize and produce plant growth-promoting compounds within the rhizosphere[6,7]. The Pseudomonas 
strains have been shown to increase plant growth and nutrient uptake of maize, wheat, and legumes in different soils and temperatures[8,9,10].

There are some reports that describe the physiological characterization of some Pseudomonas spp. isolated from different climatic regions[11,12,13]. However, knowledge about the characterization and possible function of Pseudomonas spp. in environmentally stressed conditions, such as nutrient-deficient soils within hot dry climates, is limited. In arid regions within Uzbekistan, for example, evaporation of the Aral Sea and the inappropriate application of chemical fertilizers and pesticides has resulted in pollution and salinization of soils and water courses. In the present study, Pseudomonas spp. isolated from a semi-arid region of Uzbekistan were examined and their potential role within that ecosystem discussed.

\section{MATERIALS AND METHODS}

\section{Study Sites and Soil Characterization}

Bacterial strains of Pseudomonas spp. were taken from the National Collection of Agricultural Microorganisms (NCAM) Uzbekistan. The bacterial strain P. alcaligenes PsA15 was isolated from the rhizosphere of melon, $P$. aurantiaca PsAr56 from corn, $P$. aureofaciens PsAf5 from cotton, $P$. denitrificans PsD6 from tomato, $P$. mendocina PsM13 from wheat, $P$. rathonis PsR20 from alfalfa, and $P$. stutzeri PsS23 from wheat grown in calcareous serozem soil, field site of semi-arid region. (Serozem soil conditions are shown in Table 1.)

TABLE 1

Soil Chemical Properties and Soil Particle Distribution at 0- to 30-cm Soil Layer

\begin{tabular}{|c|c|c|c|c|c|c|c|c|}
\hline \multirow[t]{2}{*}{ Type } & C & $\mathbf{N}$ & $\mathbf{P}$ & K & \multirow[t]{2}{*}{ pH } & \multicolumn{3}{|c|}{ Soil Particle Size, $\mathrm{mm}$} \\
\hline & \multicolumn{4}{|c|}{$\mathrm{mg} \cdot(100 \mathrm{~g})^{-1}$} & & $2-0.2 \%$ & $0.2-0.02 \%$ & $<0.02 \%$ \\
\hline Serozem & 200 & 0.6 & 3.0 & 12.0 & 7.5 & 2.2 & 54.5 & 43.3 \\
\hline
\end{tabular}

\section{Morphological, Physiological, and Biochemical Tests}

Production of oxidase was determined as described by Cappuccino and Sherman[14]. The catalase production was determined by adding the $\mathrm{H}_{2} \mathrm{O}_{2}(3 \% \mathrm{vol} / \mathrm{vol})$ to a bacterial culture and the presence of catalase indicated by bubbles of free oxygen gas $\left(\mathrm{O}_{2}\right)$ [14]. Formation of fluorescent pigment was observed on King B medium[15]. Production of pyocyanin was read after $3 \mathrm{~d}$ at $28^{\circ} \mathrm{C}$ with King's A medium[15]. Acid production from carbohydrates was tested in peptone water broths containing 1\% carbohydrate and Andrade's indicator[16]. Colony morphologies were examined after 24-, 48-, and 72-h growth on glycerol peptone agar (GPA) at $28^{\circ} \mathrm{C}$. Cell morphologies were examined with phase contrast microscopy and after staining with methylene blue. The oxidation and fermentation of glucose was performed according to the method of Hugh and Leifson[17].

Arginine dihydrolase was performed according to the method of Thornley[18]. Hydrolysis of starch, casein, and lecithin was determined as described by Smibert and Krieg[19]. The plates were incubated at $28^{\circ} \mathrm{C}$ and zones of starch cleaning recorded after $5 \mathrm{~d}$. Hydrolysis of Tween 20 and 60 was determined on modified sierra agar, containing $10 \mathrm{~g}$ of peptone, $3 \mathrm{~g}$ of meat extract, $5 \mathrm{~g}$ of $\mathrm{NaCl}, 0.2 \mathrm{~g}$ of Fe-citrate, 0.1 $\mathrm{g}$ of $\mathrm{CaCl}_{2} \cdot \mathrm{H}_{2} \mathrm{O}$, and $15 \mathrm{~g}$ of agar in $1 \mathrm{l}$ of distilled water. Ten ml of sterile Tween 20 and 60 and $50 \mathrm{ml}$ of $0.067 \%(\mathrm{w} / \mathrm{v})$ Victoria Blue B solution were added to the medium after autoclaving. Hydrolysis of Tween was recorded as white precipitation around the colonies. The method of Jayasankar and Graham[20] was 
used to determine the presence of pectinase and cellulase. Gelatinase activity was detected by replacing agar with gelatine as a gelling agent in GPA dispensed in stab culture tubes and by looking for liquefaction after $7 \mathrm{~d}$ incubation at $20^{\circ} \mathrm{C}$. Indol production from tryptophan was tested using the method of Clarke and Cowan[21]. Production of $\mathrm{H}_{2} \mathrm{~S}$ was read after $7 \mathrm{~d}$ incubation at $28^{\circ} \mathrm{C}$ in triple iron salts agar[16]. Acetilmethylcarbinol production was carried out according to the method of Clarke and Cowan[21]. Urease activity (Christiansen's method), citrate utilization, lipase production, hydrolysis of tryptophan, and nitrate reductase were carried out as described in Cowan[16]. Growth at different temperatures was observed in MPA medium after incubation at +4 (for $10 \mathrm{~d}$ ) and $+50^{\circ} \mathrm{C}$ (for $5 \mathrm{~d}$ ). Salt tolerance was determined in GPA medium containing $\mathrm{NaCl}$ at $7 \% \mathrm{w} / \mathrm{v}$. Auxin production was tested using Salkowsky's reagent[22]. Plant pathogenic fungi (Fusarium culmorum, Verticillum loteritum) and soil fungi (Aspergillus flavus, A. insultus, A. ustus, Penicillum purpurogenum, P. sopii, and Trichoderma lignorum) were used as indicator strains for the observation of potentially antagonistic pseudomonads using simple plate assay methods. This involved preincubation of the putative antagonist on yeast malt agar at $28^{\circ} \mathrm{C}$ for $2 \mathrm{~d}$. Plates were then seeded with individual fungal strains and incubated for a further $5 \mathrm{~d}$ in a sealed container. Zones of inhibition were then recorded.

The study of the effect of isolated strains on plant growth of wheat, corn, and tomato was carried out in pot experiments using a nutrient-poor serozem soil taken from field site. The inoculation treatments were set up in a randomized design with six replicates for each strain tested. The day before sowing, pots were filled with $350 \mathrm{~g}$ of soil. Four seeds of wheat and tomato and three seeds of corn were sown per pot. After germination, plants were thinned to two per pot. Wheat, tomato, and corn seedlings were inoculated in situ with $1 \mathrm{ml}$ of the bacterial suspension (ca. $10^{6} \mathrm{cfu} / \mathrm{ml}$ ) that was incubated on a rotary shaker (120 rpm; $26^{\circ} \mathrm{C}$ ) for $3 \mathrm{~d}$ using glycerine-peptone medium. Uninoculated plants were considered as control plants. Plants were grown in pots for 4 weeks under greenhouse conditions with a temperature of 32$34^{\circ} \mathrm{C}$ during the day and $18-22^{\circ} \mathrm{C}$ at night. The soil was moistened with sterile water and maintained at $60 \%$ of its moisture holding capacity (MHC). Four weeks after germination, the shoot and root length were measured, separated, and dried at $105^{\circ} \mathrm{C}$, before determining their respective dry weights.

The data were analyzed with an ANOVA and Student-Newman-Keuls test for testing the significant differences $(p<0.05)$ of main effects.

\section{RESULTS}

\section{Characterization of Bacteria Isolated}

Biochemical characterization of all the pseudomonads isolated is shown in Table 2. All bacterial strains studied were oxidase positive and reduced nitrate to nitrite. Three strains Pseudomonas denitrificans PsD6, $P$. rathonis PsR 20, and P. stutzeri PsS23 produced arginine dihydrolase. Only one strain, $P$. rathonis PsR20, was catalase negative. None of the strains produced fluorescein or pyocyanin. Only one strain (P. denitrificans PsD6) had lecitinase activity and two strains ( $P$. rathonis PsR20 and P. mendocina PsM13) had cellulase activity. A test for indol production was negative for all strains and urease was only produced by $P$. rathonis PSR20.

Most strains grew at $10^{\circ} \mathrm{C}$, while $P$. alcaligenes PsA15, P. stutzeri PsS23, P. aurantiaca PsAr56, and P. rathonis PsR20 grew at $50^{\circ} \mathrm{C}$. All strains except PsD6 were also tolerant to $7 \% \mathrm{NaCl}$ (Table 2).

The patterns of acid production from carbohydrates produced by the Pseudomonas isolates are shown in Table 3. Four strains produced acid from glucose and three strains produced acid from mannitol. None of the strains examined produced acids from galactose, arabinose, and xylose.

Hydrolytic reactions of the test strains showed that $P$. alcaligenes PsA15 and $P$. rathonis PsR20 hydrolyzed starch, Tween 20, and Tween 60. Starch was hydrolyzed by five of the six of strains tested (see Table 4). 
TABLE 2

Biochemical Characteristics of Pseudomonas spp.

\begin{tabular}{|c|c|c|c|c|c|c|c|}
\hline \multirow[t]{2}{*}{ Property Tested } & \multicolumn{7}{|c|}{ Bacterial Strains } \\
\hline & PsA15 & PsAf5 & PsAr56 & PsD6 & PsM13 & PsR20 & PsS23 \\
\hline Casein hydrolysis & - & - & - & - & - & - & - \\
\hline Gelatine liquefaction & + & - & - & - & - & - & - \\
\hline Citrate utilization & + & + & - & + & + & + & + \\
\hline Arginine dihydrolase & - & - & - & + & - & + & + \\
\hline Acetilmethilcarbinol & - & - & - & - & - & - & - \\
\hline Metabolism O & + & + & + & + & + & + & + \\
\hline $\mathrm{F}$ & - & - & - & - & - & - & - \\
\hline Growth at $4^{\circ} \mathrm{C}$ & - & - & - & - & - & - & - \\
\hline $50^{\circ} \mathrm{C}$ & + & - & + & - & - & + & + \\
\hline Growth at $7 \% \mathrm{NaCl}$ & + & + & + & - & + & + & + \\
\hline $\mathrm{H}_{2} \mathrm{~S}$ & + & - & - & - & + & + & + \\
\hline Oxidase & + & + & + & + & + & + & + \\
\hline Catalase & + & + & + & + & + & - & + \\
\hline Lipase & + & - & - & - & - & + & + \\
\hline Tryptophanase & - & - & - & - & - & - & - \\
\hline Nitrate reductase & + & + & + & + & + & + & + \\
\hline Amylase & + & - & - & - & - & + & + \\
\hline Collagenase & + & - & - & - & - & + & - \\
\hline Pectinase & + & - & + & - & - & - & + \\
\hline Lecithinase & - & - & - & + & - & - & - \\
\hline Cellulase & - & - & - & - & + & + & - \\
\hline Urease & - & - & - & - & - & + & - \\
\hline
\end{tabular}

TABLE 3

Carbohydrate Fermentation Pattern of Pseudomonas spp.

\begin{tabular}{lccccccc}
\hline Acid Source & PsA15 & PsAf5 & PsAr56 & PsD6 & PsM13 & PsR20 & PsS23 \\
\hline Arabinose & - & - & - & - & - & - & - \\
Xylose & - & - & - & - & - & - & - \\
Glucose & + & - & - & - & + & + & + \\
Galactose & - & - & - & - & - & - & - \\
Saccharose & + & - & - & - & - & - & - \\
Lactose & - & - & - & - & - & - & + \\
Maltose & - & - & - & - & - & - & + \\
Glycerol & - & - & - & - & + & - & + \\
Mannitol & - & - & - & - & + & + & + \\
\hline
\end{tabular}

The microbial production of antifungal metabolites by bacteria provides an important source of useful molecules within any ecosystem. All six pseudomonads isolated were antagonistic to one or more of the soil fungi A. flavus, A. insultus, A. ustus, Penicillum purpurogenum, P. sopii, and T. lignorum. The growth of most of the above fungi was strongly inhibited by Pseudomonas aureofaciens PsAf5 (Table 5). Only two strains ( $P$. alcaligenes PsA15 and $P$. denitrificans PsD6) were antagonist towards the plant pathogenic fungus Vertilcillum loteritum (data not shown). 
TABLE 4

Activity of Pseudomonas spp. to Hydrolyze Starch and Tween in situ

\begin{tabular}{lccc}
\hline Bacterial Strains & Starch $(\mathbf{c m})$ & Tween $\mathbf{2 0}(\mathbf{m m})$ & Tween $\mathbf{6 0}(\mathbf{m m})$ \\
\hline P. alcaligenes PsA15 & $1.5^{\star}$ & 2.2 & 2 \\
P. aureofaciens PsAf5 & 6 & - & - \\
P. denitrificans PsD6 & - & - & - \\
P. rathonis PsR20 & 2.5 & - & - \\
P. stutzeri PsS23 & 3.8 & 3 & - \\
P. stutzeri PsS25 & 3.5 & & \\
\hline
\end{tabular}

* Diameter of hydrolytic zone in $\mathrm{cm}$.

TABLE 5

Antagonistic Activity of Pseudomonas spp. Against Nonpathogenic Fungi

\begin{tabular}{|c|c|c|c|c|c|c|}
\hline $\begin{array}{l}\text { Bacterial } \\
\text { Strains }\end{array}$ & $\begin{array}{l}\text { Aspergillus } \\
\text { flavus }\end{array}$ & $\begin{array}{l}\text { Aspergillus } \\
\text { insultus }\end{array}$ & $\begin{array}{c}\text { Aspergillus } \\
\text { ustus }\end{array}$ & $\begin{array}{c}\text { Penicillum } \\
\text { purpurogenum }\end{array}$ & $\begin{array}{c}\text { Penicillium } \\
\text { sopii }\end{array}$ & $\begin{array}{c}\text { Trichoderma } \\
\text { lignorum }\end{array}$ \\
\hline PsA15 & - & 2* & - & $3^{*}$ & $2 *$ & $3^{*}$ \\
\hline PsAf5 & $3^{*}$ & $3^{*}$ & $2 *$ & - & $2^{\star}$ & - \\
\hline PsD6 & - & $2^{\star}$ & - & - & $2^{\star}$ & $2^{\star}$ \\
\hline PsM13 & $3^{*}$ & - & - & $2^{\star}$ & - & $2^{*}$ \\
\hline PsR20 & - & $2^{*}$ & $4^{*}$ & - & - & $3^{*}$ \\
\hline PsS23 & - & $2^{*}$ & - & - & - & $2^{\star}$ \\
\hline
\end{tabular}

* Inhibition zone in $\mathrm{mm}$.

A rapid screening of auxin production showed that two bacterial isolates produced auxins. These were $P$. alcaligenes PsA15, which produced $3.2 \mu \mathrm{g}$ IAA $100 \mathrm{ml}^{-1}$ filtrate, and $P$. denitrificans PsD6, which produced $3.0 \mu \mathrm{g}$ IAA $100 \mathrm{ml}^{-1}$ filtrate (data not shown).

In terms of improved plant growth, some of the bacterial strains examined increased the growth (expressed as shoot and root lengths) of wheat, corn, and tomato in a nitrogen-deficient soil. Independent of the origin from where bacterial strains have been isolated, P. denitrificans PsD6, P. rathonis PsR20, and P. aureofaciens PsAf5 increased the shoot and root length of wheat and corn (from 30-45\%) compared to the control plants (Figs. 1 and 2). The inoculation of tomato also resulted in increase of shoot and root length of plant grown in serozem soil (Fig. 3)

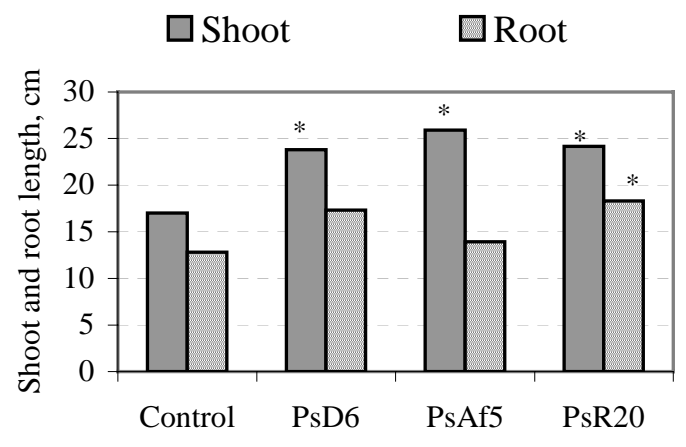

FIGURE 1. Effect of Pseudomonas spp. on shoot and root growth of wheat, $P$. denitrificans PsD6, $P$. aureofaciens PsAf5, and P. rathonis PsR20. *Significant differences, $p<0.05$. 


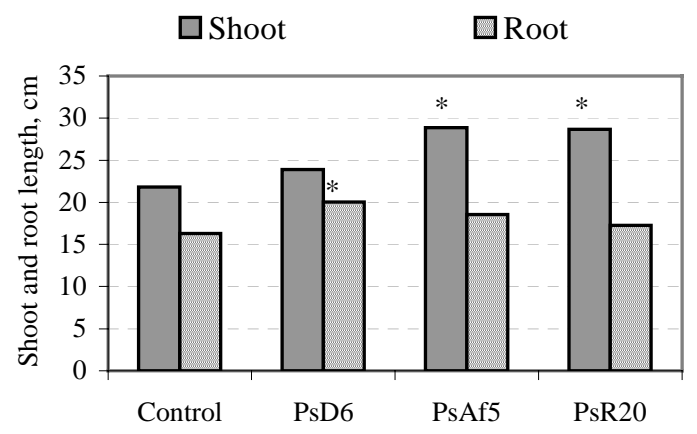

FIGURE 2. Effect of Pseudomonas spp. on shoot and root growth of maize, $P$. denitrificans PsD6, $P$. aureofaciens PsAf5, and $P$. rathonis PsR20. * Significant differences, $p<0.05$.

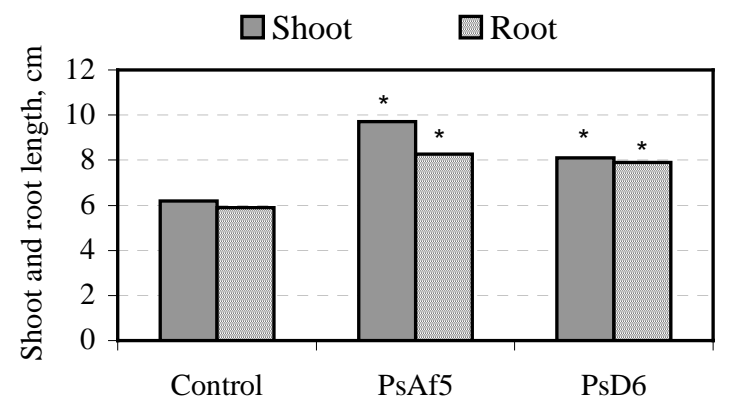

FIGURE 3. Effect of Pseudomonas spp. on shoot and root length of tomato, $P$. denitrificans PsD6, and P. aureofaciens PsAf5. *Significant differences, $p$ $<0.05$.

\section{DISCUSSION}

Pseudomonads are well suited to the rhizosphere because they are able to use a wide variety of carbon sources as nutrients. Like many rhizosphere bacteria, they play a role in nutrient cycling, can be plant growth-promoting rhizobacteria (PGPR), and may act as biological control agents (BCA). They exhibit a wide range of metabolic activities and are able to utilize a wide range of low molecular mass organic compounds, and some more complex compounds, as carbon and energy sources[23].

In early studies, Stainer et al.[24] described the remarkable capacity of Pseudomonas strains to degrade a wide range of substrates including aromatic compounds, halogenated derivatives, and growth characteristics of 267 strains on 146 different organic compounds, plus a wide range of associated tests. In this present work, we describe the biochemical and physiological characterization of Pseudomonas strains isolated from alfalfa, corn, cotton, melon, tomato, and wheat grown in a calcareous serozem soil, in a semi-arid region of Uzbekistan.

Our Pseudomonas strains produce different biologically active compounds. There are many reports that note the production of biologically active compounds including different enzymes, phytohormones (such as auxins), and also siderophores by rhizosphere bacteria[9,10,25,26]. The bacterial strains that produce different hydrolytic enzymes such as protease, lipase, and pectinase were effected antagonistically to soil fungi. Abd Rahman et al.[27], Caballero et al.[28], and Hutberg et al [29] reported that among studied pseudomonads, the $P$. aureginosa produced several proteases that have implicated in its pathogenicity. Neiendam Nielson and Sorensen[30] demonstrated that isolates of $P$. fluorescens antagonistic to Rhizoctonia solani and Pythium ultimum, produced lytic enzymes. 
Organic substances capable of regulating plant growth produced either endogenously or applied exogenously are called plant growth regulators. They regulate growth by affecting physiological and morphological processes at very low concentrations[31]. Microbial IAA has been implicated in the stimulation of growth of plants[22]. A diverse group (including pseudomonads) has been found to synthesize IAA[32]. IAA influences root length due the hormonal effect. In this study, two bacterial strains produced considerable amounts of IAA, which are comparable with earlier studies on various bacteria including Pseudomonas[33,34]. Dey et al.[35] reported that Pseudomonas spp. strains isolated from peanut produced IAA and inhibited a fungal pathogen including A. niger. Seed bacterization of these isolates increased the root length and plant height in pots significantly over the control. Pseudomonas spp. strains isolated from the rhizosphere of maize, wheat, rice, and soybean produced IAA, utilized starch, and were positive for lipase activity. Monosaccharides (glucose, mannitol fructose, and sorbitol) were utilized by all the bacterial isolates[34].

The ability of the seven isolates of Pseudomonas spp. from this study to tolerate high temperatures and salt concentrations thus uncommon among terrestrial pseudomonads thus confer on the isolates a potential competitive advantage to survive in arid and saline regions of the world.

Coupled with their ability to survive in warm saline climates, bacteria $P$. denitrificans PsD6, $P$. aureofaciens PsAf5, and P. rathonis PsR20 were shown, under glasshouse experimental conditions, to contribute towards the increased plant growth of wheat, corn, and tomato in soils; while nontreated control plants by comparison also performed poorly under such conditions.

De Freitas and Germida[36] also demonstrated that in a low-fertility soil, pseudomonads significantly enhanced early plant growth of winter wheat. According to Lazarovitz and Nowak[37], rhizosphere bacterization of crop plants only marginally increased yields when tested under ideal climatic situations and greatest benefits in terms of improved plant health and yield were obtained when crops encountered environmental stress (e.g., elevated temperatures) for prolonged periods. Some successful examples of inoculation with PGPR have been achieved both in laboratory and field trials. For example, strains of $P$. putida and $P$. fluorescens could increase root and shoot elongation in canola, lettuce, and tomato[38]. $P$. aureofaciens strain AB254 increased seedling emergence compared with that of untreated seed of corn[39].

In conclusion, based on this study, we have shown that Pseudomonas spp. isolated from the semi-arid saline serozem soil of Uzbekistan have the potential to produce different biologically active compounds and may have the ability to survive in ecologically stressed conditions including hot summer temperatures and saline and nitrogen-deficient soils. In addition, some strains have the ability to increase plant growth and stimulate early growth. Further work is required to trial an appropriate mix of strains in order to develop pilot "biofertilizers" for use in the Uzbek agricultural system. Such biofertilizers may offer the potential of an alternative, improved, and more environmentally friendly regime than does the current status quo in Uzbek agricultural practice.

\section{ACKNOWLEDGMENT}

The author would like to thank Dr. Peter Green (NCIMB UK) for supervision and critical comments on the manuscript.

\section{REFERENCES}

1. Atlas, R.M., Horowitz, A., Krichevsky, M., and Bej, A.K. (1991) Response of microbial populations to environmental disturbance. Microb. Ecol. 22, 249-256.

2. $\quad$ Garland, J.L. and Mills, A.L. (1994) A community-level physiological approach for studying microbial communities. In Beyond the Biomass: Compositional and Functional Analysis of Soil Microbial Communities. Ritz, K., Dighton, J., and Giller, K.E., Eds. John Wiley \& Sons. Chichister. pp. 77-83. 
3. Zak, D.R., Tilman, D., Parmenter, R.R., Fisher, F.M., Vose, J., Milchunas, D., and Martin, C.W. (1994) Plant production and soil microorganisms in late-successional ecosystems: a continental-scale study. Ecology 75, 23332347.

4. $\quad$ Spiers, A.J., Buckling, A., and Rainey, P.B. (2000) The causes of Pseudomonas diversity. Microbiology 146, 23452350.

5. Germida, J.J. and Siciliano, S.D. (2001) Taxonomic diversity of bacteria associated with the roots of modern, recent and ancient wheat cultivars. Biol. Fertil. Soils 33, 410-415.

6. $\quad$ Cook, R.J., Thomashow, L.S., Weller, D.M., Fujimoto, D., Mazzola, M., Banger, G., and Kim, D.S. (1995) Molecular mechanisms of defense by rhizobacteria against root diseases. Proc. Natl. Acad. Sci. U. S. A. 92, 4197-4201.

7. $\quad$ De Weger, L.A., Van der Bij, A.J., Dekkers, L.C., Simons, M., Wijffelmann, C.A., and Lugtenberg, B.J.J. (1995) Colonisation of the rhizosphere of crop plants by plant-beneficial pseudomonads. FEMS Microbiol. Ecol. 17, 221228.

8. Kloepper, J.W. and Beauchamp, C.J. (1992) A review of issues related to measuring of plant roots by bacteria. Can. J. Microbiol. 38, 1219-1232.

9. Höflich, G., Wiehe, W., and Kühn, G. (1994) Plant growth stimulation with symbiotic and associative rhizosphere microorganisms. Experientia 50, 897-905.

10. Höflich, G. and Kühn, G. (1996) Förderung das Wachstums und der Nährstoffaufnahme bei kurziferen Öl- und Zwischenfruhten durch inokulierte. Rhizospherenmikroorganismen. Z. Pflanzenernähr. Bodenkd. 159, 575-578.

11. Latour, X., Corberand, T., Laguerre, G., Allard, F., and Lemanceau, P. (1996) The composition of fluorescent Pseudomonas populations associated with roots is influenced by plant and soil type. Appl. Environ. Microbiol. 62, 2449-2456.

12. Simon, R., Hötte, B., Klauke, B., and Kosier, B. (1991) Isolation and characterisation of insertion sequence elements from Gram negative bacteria by using new broad host range positive selection vectors. J. Bacteriol. 173, 1502-1508.

13. Sands, D.C. and Rovira, D. (1971) Pseudomonas fluorescens biotype G, the dominant fluorescent pseudomonad in South Australian soils and wheat rhizosphere. J. Appl. Bacteriol. 34, 261-275.

14. Cappuccino, J.G. and Sherman, N. (2001) Microbiology: A Laboratory Manual. Benjamin Cummings, San Francisco. p. 185.

15. King, E.O., Ward, M.K., and Ranev, D.E. (1954) Two simple methods for the determination of pyocyanin and fluorescin. J. Lab. Clin. Med. 44, 301-304.

16. Cowan, S.T. (1974) Cowan and Steel's Manual for the Identification of Medical Bacteria. Cambridge University Press.

17. Hugh, R. and Leifson, E. (1953) The taxonomic significance of fermentative versus oxidative metabolism of carbohydrates by various Gram-negative bacteria. J. Bacteriol. 66, 24-26.

18. Thornley, M. (1960) The differentiation of Pseudomonas from other Gram-negative bacteria on the basis of arginine metabolism. J. Appl. Bacteriol. 23, 37-52.

19. Smibert, R.M. and Krieg, N.R. (1994) Phenotypic characterization. In Methods for General and Molecular Bacteriology. Gerhardt, P. et al., Eds. American Society for Microbiology, Washington, D.C. pp. 607-654.

20. Jayasankar, N.P. and Graham, P.H. (1970) An agar plate method for screening and enumerating pectinolytic microorganisms. Can. J. Microbiol. 16, 1023-1025.

21. Clarke, P.H. and Cowan, S.T. (1952) Biochemical methods for microbiology. J. Gen. Microbiol. 6, 187.

22. Sarwar, M., Arshad, A.D., Martens, W.T., and Frankenberger, J.R. (1992). Tryptophan dependent biosynthesis of auxins in soil. Plant Soil 147, 207-215.

23. Misko, A.L. and Germida, J. (2002) Taxonomic and functional diversity of pseudomonads isolated from the roots of field-grown canola. FEMS Microbiol. Ecol. 42, 399-407.

24. Stainer, R.Y., Palleroni, N.J., and Duodorof, M. (1966) The aerobic pseudomonads: a axonomic study. J. Gen. Microbiol. 43, 159-271.

25. Kloepper, J.W., Leong, J., Teintze, M., and Schroth, M.N. (1980) Pseudomonas siderophores: a mechanism explaining disease-suppressive soils. Curr. Microbiol. 4, 317-320.

26. Höflich, G., Wiehe, W., and Heght-Buchholz, C.H. (1995) Rhizosphere colonization of different growth promoting Pseudomonas and Rhizobium bacteria. Microbiol. Res. 150, 139-147.

27. Abd Rahman, R.N.Z., Geok, L.P., Basri, M., and Abd Rahmen, B.S. (2005) Physical factors affecting the production of organic solvent-tolerant protease by Pseudomonas aeruginosa strain K. Bioresour. Technol. 96, 429-436.

28. Caballero, A.R., Moreau, J.M., Engel, L.S., Marquart, M.E., Hill, J.M., and O’Callaghan, R.J. (2001) Pseudomonas aeruginosa protease IV enzyme assays and comparison to other Pseudomonas proteases. Anal. Biochem. 290(2), 330337.

29. Hultberg, M., Alsanius, B., and Sundin, P. (2000) In vivo and in vitro interactions between Pseudomonas fluorescens and Pythium ultimum in the suppression of damping-off in tomato seedlings. Biol. Control 19, 1-8.

30. Neiendam Nielson, M. and Sorensen, J. (1999) Chitinolytic activity of Pseudomonas fluorescens isolates from barley and sugar beet rhizosphere. FEMS Microbiol. Ecol. 30, 217-227.

31. Arshad, M. and Frankenberger, W.T.J. (1998) Plant growth-regulating substances in the rhizosphere: microbial production and function. Adv. Agron. 62, 145-151. 
32. Patten, C.L. and Glick, B.R. (2000) Role of Pseudomonas putida indoleacetic acid in development of the host plant root system. Appl. Environ. Microbiol. 68, 3795-3801.

33. Malik, K.A., Bilal, R., Mehnaz, S., Rasul, G., Mirza, M.S., and Ali, S. (1997) Association of nitrogen-fixing, plantgrowth-promoting rhizobacteria (PGPR) with kallar grass and rice. Plant Soil 194, 37-44.

34. Park, M., Kim, C., Yang, J., Lee, H., Shin, W., Kim, S., and Sa, T. (2005) Isolation and characterization of diazotrophic growth promoting bacteria from rhizosphere of agricultural crops of Korea. Microbiol. Res. 160(2), 127133.

35. Dey, R., Pal, K.K., Bhatt, D.M., and Chauhan, S.M. (2004) Growth promotion and yield enhancement of peanut (Arachis hypogaea L.) by application of plant growth-promoting rhizobacteria. Microbiol. Res. 159, 371-394.

36. De Freitas, J. and Germida, J.J. (1992a). Growth promotion of winter wheat fluorescent Pseudomonas under growth chamber conditions. Soil Biol. Biochem. 24, 1127-1135.

37. Lazarovitz, G. and Nowak, J. (1997) Rhizobacteria for improvement of plant growth and establishment. Hortic. Sci. 32, 188-192.

38. Glick, B.R., Changping, L., Sibdas, G., and Dumbroff, E.B. (1997) Early development of canola seedlings in the presence of the plant growth-promoting rhizobacterium Pseudomonas putida GR12-2. Soil Biol. Biochem. 29, 12331239.

39. Mathre, D.E., Callan, N.W., Johnston, R.H., Miller, J.B., and Schwend, A. (1994) Factors influencing the control of Pythium ultimum-induced seed decay by seed treatment with Pseudomonas aureofaciens AB254. Crop Protect. 13, 301-307.

This article should be referenced as follows:

Egamberdiyeva, D. (2005) Characterization of Pseudomonas species isolated from the rhizosphere of plants grown in serozem soil, semi-arid region of Uzbekistan. TheScientificWorldJOURNAL 5, 501-509.

\section{Handling Editor:}

A.R. Mermut, Principal Editor for Soil Systems — a domain of TheScientificWorldJOURNAL.

\section{BIOSKETCH}

Dilfuza Egamberdiyeva is a head of the Soil Microbiology and Plant-Microbe Interactions Laboratory and curator of the National Collection of Agricultural Microorganisms (NCAM) at the University of Agriculture, Uzbekistan. She holds degrees in agriculture from the Humboldt University of Berlin, Germany. Her current research interests lie in microbial diversity and community analysis, rhizobacteria, plant microbe interactions research, biological control, and development of bacterial fertilizers for agricultural practices. 

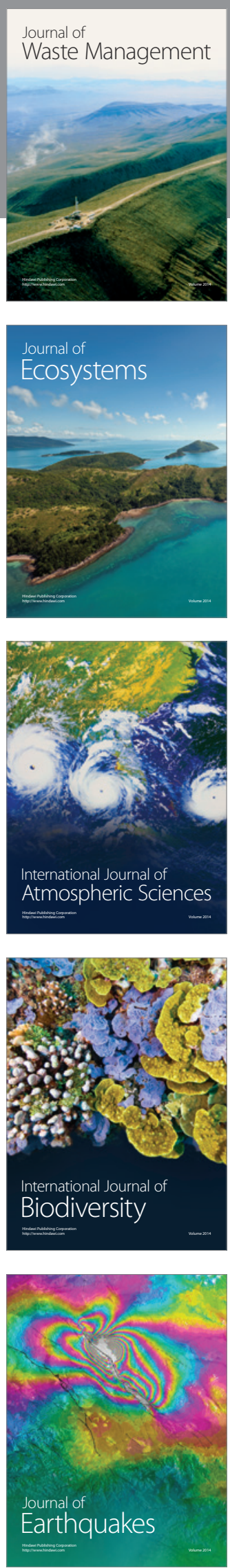
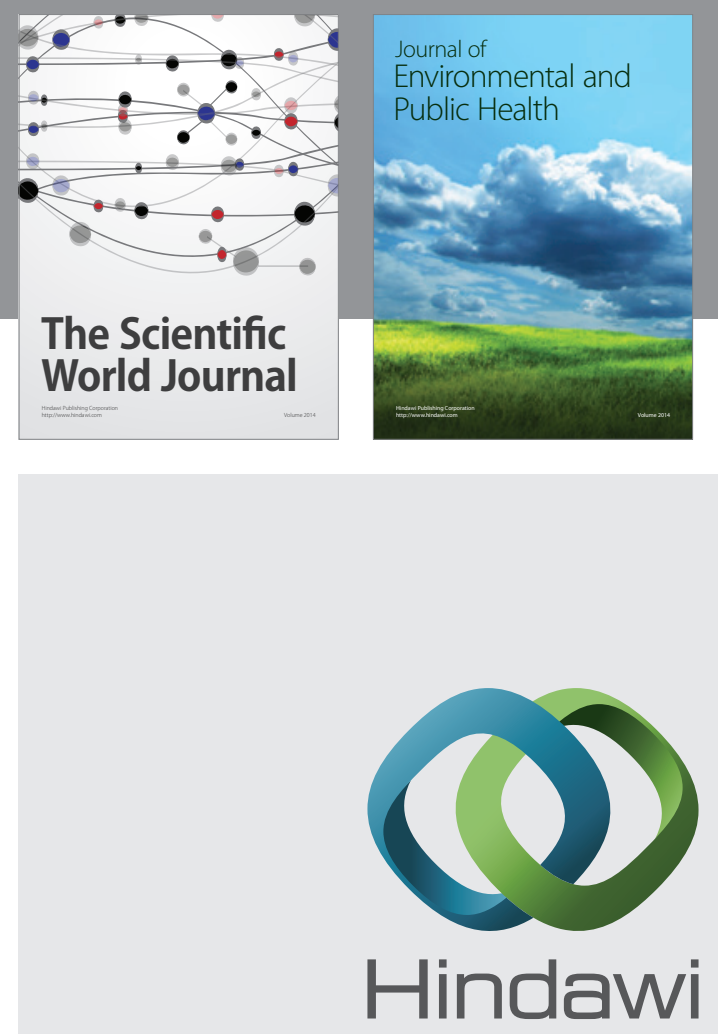

Submit your manuscripts at

http://www.hindawi.com
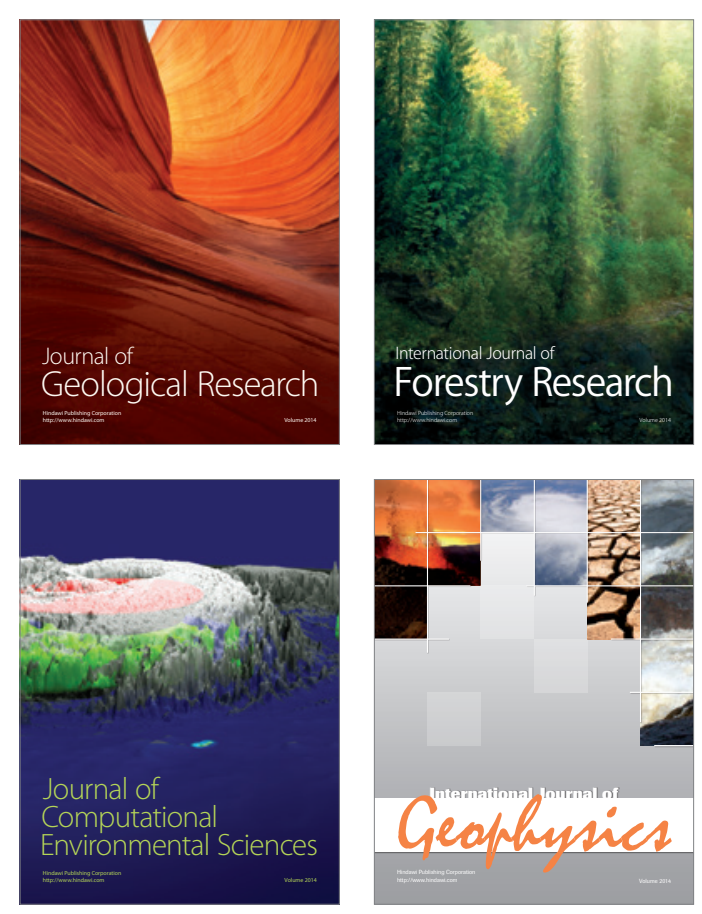
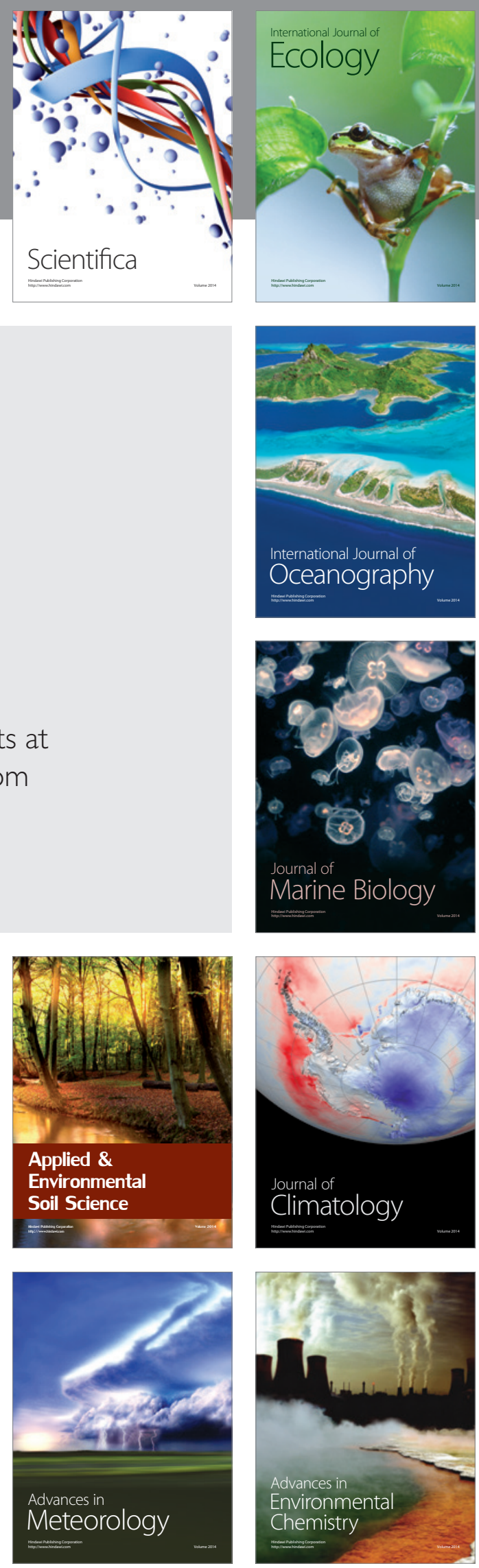